\title{
Sporothrix schenckii and Sporotrichosis
}

\author{
LEILA M. LOPES-BEZERRA ${ }^{1}$, ARMANDO SCHUBACH ${ }^{2}$ and ROSANE O. COSTA ${ }^{3}$ \\ ${ }^{1}$ Universidade do Estado do Rio de Janeiro/UERJ \\ Instituto de Biologia Roberto Alcantara Gomes, Departamento de Biologia Celular e Genética \\ Rua São Francisco Xavier, 524 PHLC, sl. 205, Maracanã \\ 20550-013 Rio de Janeiro, RJ, Brasil \\ ${ }^{2}$ Instituto Oswaldo Cruz, Instituto de Pesquisa Clínica Evandro Chagas \\ Departamento de Doenças Infecciosas, Av. Brasil 4365, Manguinhos \\ 21040-900 Rio de Janeiro, RJ, Brasil \\ ${ }^{3}$ Universidade do Estado do Rio de Janeiro/UERJ, Hospital Universitário Pedro Ernesto \\ Av. 28 de Setembro 77, Vila Isabel, 20551-900 Rio de Janeiro, RJ, Brasil
}

Manuscript received on September 26, 2005; accepted for publication on October 10, 2006

presented by LUIZ R. TRAVASSOS

\begin{abstract}
For a long time sporotrichosis has been regarded to have a low incidence in Brazil; however, recent studies demonstrate that not only the number of reported cases but also the incidence of more severe or atypical clinical forms of the disease are increasing. Recent data indicate that these more severe forms occur in about $10 \%$ of patients with confirmed diagnosis. The less frequent forms, mainly osteoarticular sporotrichosis, might be associated both with patient immunodepression and zoonotic transmission of the disease. The extracutaneous form and the atypical forms are a challenge to a newly developed serological test, introduced as an auxiliary tool for the diagnosis of unusual clinical forms of sporotrichosis.
\end{abstract}

Key words: sporotrichosis, diagnosis, epidemiology, drugs, cell wall, antigens.

\section{Sporothrix schenckii}

Sporotrichosis was described for the first time by Benjamin Schenck in 1898, when he was a medical student at the Johns Hopkins Hospital in Baltimore. After isolation of the etiological agent, Schenck sent the sample to the mycologist Erwin Smith who concluded that the agent was a microorganism of the genus Sporotrichum. In 1900, the disease was reported for the second time by Hektoen and Perkins who classified the etiological agent as Sporothrix schenckii, with the pathogen being isolated from a specimen aspirated from the cu-

Correspondence to: Dr. Leila M. Lopes Bezerra E-mail: leila@uerj.br taneous lesions of the patient (Hektoen and Perkins 1900). In Europe, the first case was described in 1903 and more than 200 cases were reported over the following 10 years (Mariat 1968). The first case of sporotrichosis in Brazil was reported in 1907 by Lutz and Splendore, who also found that it was possible to culture the yeast form in vitro (Lutz and Splendore 1907). The dimorphic transition of this fungus was described by Howard (1961). Sporothrix schenckii is therefore a dimorphic pathogenic fungus and the etiological agent of human and animal sporotrichosis. The fungus belongs to the subdivision Deuteromycotina, class Hyphomycetes (KwonChung and Bennett 1992). According to Mariat (1971) and Taylor (1970), the fungus Ceratocys- 
tis stenoceras (Ophiostoma stenoceras) presents a conidial stage similar to that of $S$. schenckii; however, no conclusions exist regarding the description of the teleomorphic phase of this species (Travassos and Lloyd 1980). Other investigators have recently postulated that $O$. stenoceras may correspond to the teleomorph of S. schenckii (Lacaz et al. 2002, Beer et al. 2003). Previous studies based on DNA hybridization experiments, however, provided strong evidence that $O$. stenoceras is not the teleomorph of S. schenckii. The degree of hybridization observed among $S$. schenckii and O. stenoceras DNAs was as low as $30 \%$ while a high degree of cross-hybridization was observed among the four S. schenckii strains studied (reviewed by Travassos 1985).

Sporothrix schenckii is widely distributed in nature and can be found in soil associated with plant organic matter (for example, thorns, dry leaves and wood), water, and decomposing organic matter, among others. Clinical isolates of S. schenckii produce raised moist colonies with a membranous aspect and a wrinkled or folded surface. In principle, the colonies are white to cream colored, later turning brown to dark gray and black. During subculture, the colonies may irreversibly lose their dark color, becoming creamy white (Lacaz 1998).

This fungus is dimorphic with a mycelial phase and a yeast phase (Howard 1961). The mycelial saprophytic phase is characterized by slender, hyaline, septate and branched hyphae containing thin conidiophores whose apex forms a small vesicle with sympodially arranged denticles. Each denticle produces one conidium, each measuring approximately 2 to $4 \mu \mathrm{m}$ and these conidia are arranged in flower-like groups. The conidia become detached from the conidiophores, sometimes being arranged side by side in a row bilaterally to the hyphae. The yeast parasitic phase is pleomorphic, showing spindle-shaped and/or oval cells measuring 2.5 to $5 \mu \mathrm{m}$ in diameter and resembling a "cigar". In vitro, the mycelial and yeast phases can be obtained by culture at $25^{\circ} \mathrm{C}$ and $37^{\circ} \mathrm{C}$, respectively, or by varying the culture medium (Men- donça et al. 1976). Factors such as aeration, $\mathrm{CO}_{2}$ tension, $\mathrm{pH}$, carbon source and the presence of divalent cations may influence the morphological transition (Rodriguez-Del Valle et al. 1983, Alsina and Rodriguez-Del Valle 1984); however, temperature is a determining factor in dimorphism.

\section{BIOCHEMICAL ASPECTS OF THE S. schenckii SURFACE}

The cell wall is the surface envelope of the fungal cell and plays a central role in pathogen-host interaction, thus mediating various processes associated with the pathogenesis of these microorganisms. The cell wall of $S$. schenckii consists of alkali-soluble and -insoluble glucans found in both morphological phases of this fungus. Alkali-soluble glucans of the yeast form of $S$. schenckii are linked by $\beta(1,3)$, $\beta(1,6)$ and $\beta(1,4)$ bonds at 44,28 and $28 \%$, respectively. Insoluble glucans contain 66, 29 and 5\%, respectively, of $\beta(1,3), \beta(1,6)$ and $\beta(1,4)$ bonds. No variations in $\beta$-glucan composition have been observed with the morphological transition of $S$. schenckii (Previato et al. 1979).

The presence of melanin in the cell wall may have a protective role in this pathogen since this pigment functions as a scavenger of free radicals (Romero-Martinez et al. 2000, Morris-Jones et al. 2003).

Few protein or glycoprotein components have been identified so far in the cell wall of this fungus. The outermost layer of the cell wall of $S$. schenckii consists of amorphous microfibrillar material, formerly called capsular material, which detaches from the cell wall being released in the medium (Garrisson and Mirikitani 1983). Recent studies have shown that such microfibrillar layer is involved in the adhesion of this fungus to host cells (Figueiredo et al. 2004).

A glycoprotein fraction containing $33.5 \%$ rhamnose, $57 \%$ mannose and $14.2 \%$ protein, called peptidorhamnomannan, was isolated from the cell wall of the yeast phase of S. schenckii (Lloyd and Bitoon 1971). In parallel, a glycoconjugate containing rhamnose and mannose was detected in a frac- 
tion isolated from the culture filtrate of S. schenckii (Ishizaki 1970). The peptidorhamnomannan glycopeptide fraction reacted with sera from patients with sporotrichosis and with concanavalin A (Con A) (Lloyd and Bitoon 1971, Travassos et al. 1977). Besides, this fraction inhibited the adhesion of this fungus to extracellular matrix proteins, suggesting the presence of adhesins on the surface of this pathogen (Lima et al. 2001, 2004). In addition to rhamnose and mannose, polysaccharides containing galactose have also been identified on the surface of this fungus, suggesting the presence of a galactomannan (Mendonça et al. 1976, MendonçaPreviato et al. 1980). A peptidorhamnogalactan was obtained by extraction from yeast-like cells with deoxycholate and subsequent chromatography on a DEAE-Sephadex column (Nakamura 1976). Structural studies on the rhamnomannan fraction obtained by extraction with $2 \% \mathrm{KOH}$ at $100^{\circ} \mathrm{C}$ showed the presence of mono- and dirhamnoside side chains bound to a main chain of $\alpha 1 \rightarrow 6$ linked mannosyl residues (Travassos et al. 1973, 1974). Glucuronic acid residues have also been described in an acidic fraction of rhamnomannans from S. schenckii (Gorin et al. 1977).

The reactivity of the $S$. schenckii cell wall with ConA has been observed by electron microscopy in both mycelial and yeast phases of this fungus (Travassos et al. 1977). Immunocytochemical analysis of antigens in the outermost layer of yeast cells of $S$. schenckii revealed labeling of these antigens by polyclonal antibodies co-localized with regions reactive with ConA (Castillo et al. 1990). Although containing antigenic epitopes, however, the rhamnomannan chains described thus far did not contain ConA-binding ligands in their structure (Lloyd and Travassos 1975, Lloyd et al. 1978). Whereas rhamnomannans showed no reactivity with ConA in double diffusion precipitation tests, the glycopeptide fraction (peptidorhamnomannan) reacted with this lectin (Travassos et al. 1977). Oligosaccharide chains O-linked to peptidorhamnomannan containing up to 5 monosaccharide units were subsequently characterized, revealing the pres- ence of $\alpha$-D-mannose, $\alpha$-D-glucuronic acid and $\alpha$-L-rhamnose residues (Lopes-Alves et al. 1992). The presence of 2-O-substituted $\alpha$-D-mannopyranoside units in these oligosaccharides and of terminal nonreducing mannose residues in the O-linked disaccharide explains the reactivity of the fungal cell wall with ConA (Lopes-Alves et al. 1992). In addition, O-glycoside chains showed important antigenic determinants involving $\alpha$-D-glucuronic acid residues mono- and disubstituted by terminal nonreducing rhamnose residues (Figure 1) (Lopes-Alves et al. 1994).

\section{EPIDEMIOLOGY}

Sporotrichosis has been mainly reported in tropical and temperate zones (Conti-Diaz 1980, Fukushiro 1984, Itoh et al. 1986, Kwong-Chung and Bennett 1992, Eisfelder et al. 1993, Chakrabarti et al. 1994, Vismer and Hull 1997, Pappas et al. 2000, Espinosa-Texis et al. 2001, Barros et al. 2004, Schubach et al. 2004). In the south of the American continent the disease more frequently occurs in the humid autumn or in summer (Mackinnon et al. 1969, Lopes et al. 1999), whereas in Mexico the highest incidence is observed in cold and dry seasons (González-Ochoa 1965). No seasonal difference, however, has been reported by other authors (Vismer and Hull 1997, Lyon et al. 2003, Barros et al. 2004).

Sporotrichosis can affect all ages (Rippon 1988, Vismer and Hull 1997) and the number of cases involving men and women varies from region to region (González-Ochoa 1965, Muir and Pritchard 1984, Itoh et al. 1986, Rippon 1988, Barros et al. 2004). In some regions, the difference in the distribution of cases according to age and gender might be explained by the type of fungal exposure (Fukushiro 1984, Kusuhara et al. 1988, Lyon et al. 2003), but no association has been found in other regions (Pappas et al. 2000).

Generally, infection results from inoculation of the fungus through thorns, splinters, scratches and small traumas during leisure and occupational ac- 


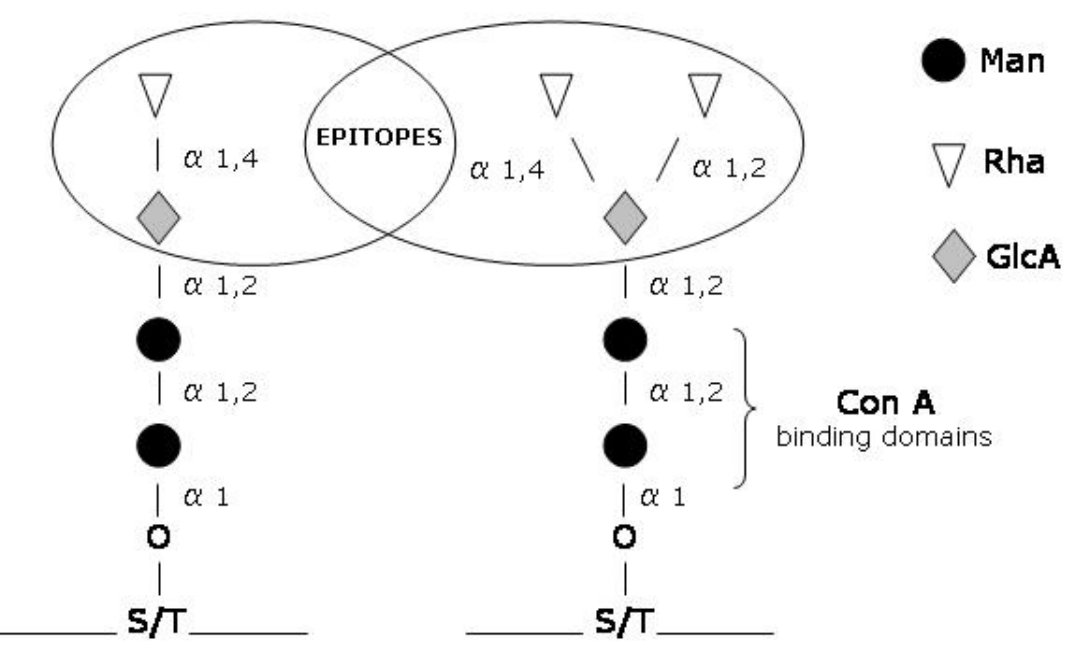

Fig. 1 - Structure of O-glycosidic-linked tetra- and pentasaccharides of S. schenckii cell wall peptido-rhamnomannans showing the main epitopes and the Con A binding residues (adapted from Lopes-Alves et al. 1992).

tivities such as floriculture, horticulture, gardening, fishing, hunting, farming and cattle raising, mining, and wood exploration (Mackinnon et al. 1969, Mayorga et al. 1978, 1979, Read and Sperling 1982, Rippon 1988, Kauffman 1999, Lopes et al. 1999, Pappas et al. 2000, Barros et al. 2003). Laboratory professionals can be infected accidentally while manipulating $S$. schenckii cultures (Thompson and Kaplan 1977, Cooper et al. 1992).

Sporotrichosis usually occurs in isolated cases or in small family or professional outbreaks. Epidemics are rare and, if present, have been related to a single source of infection (Campos et al. 1994, Bustamante and Campos 2001). The largest epidemic so far reported occurred in South Africa, with about 3000 gold miners being infected with the fungus which occurred in the wood girders of the mine structure (Quintal 2000). Another epidemic burst affected 84 workers who participated in reforestation programs in 15 states of the United States and was associated with the sphagnum moss used to store the seedlings originating from Pennsylvania (CDC 1988).

Human sporotrichosis has been sporadically related to the scratch or bite of animals (Moore and Davis 1918, Kauffman 1999). However, the presence of the fungus in the mouth or nails of the animals was not demonstrated in any of the cases described (Moore and Davis 1918, Fischman et al. 1973). Since the 1980 s, domestic cats have gained importance in the transmission of the mycosis to man (Read and Sperling 1982, Dunstan et al. 1986a, b, Larsson et al. 1989, Reed et al. 1993, Werner and Werner 1994, Schubach and Schubach 2000).

The largest epidemic of sporotrichosis due to zoonotic transmission was described in Rio de Janeiro (Barros et al. 2001). Between 1998 and 2004, only at the Evandro Chagas Clinical Research Institute, Fiocruz, 1503 cats, 64 dogs and 759 humans (Figure 2) have been diagnosed by isolation of S. schenckii in culture (Barros et al. 2004, Schubach et al. 2004, 2006). As a rule, feline disease preceded human and canine diseases, and the individuals most frequently affected included housewives taking care of cats with sporotrichosis (Barros et al. 2004). Domiciliary or professional contact with sick cats was observed in $84.1 \%$ of the canine cases and in $84.7 \%$ of the human cases. Among the latter, $57.1 \%$ reported a history of a scratch or bite.

To investigate the potential of cats as a pos- 


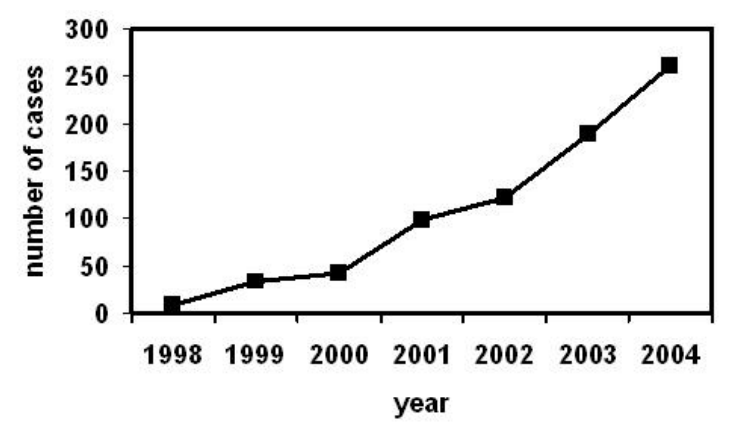

Fig. 2-Number of human cases registered at the Evandro Chagas Research Institute between 1998 and 2004.

sible source of infection, 148 cats with sporotrichosis and 84 apparently healthy cats in domiciliary contact with the affected animals were studied regarding the presence of $S$. schenckii in different biological materials. The fungus was isolated from $100 \%$ of cutaneous lesions, $47(\mathrm{n}=71,66.2 \%)$ nasal cavity swabs, $33(\mathrm{n}=79,41.8 \%)$ oral cavity swabs, and $15(\mathrm{n}=38,39.5 \%)$ pools of nail fragments from cats with sporotrichosis. Sporothrix schenckii was also isolated from oral swabs of three $(\mathrm{n}=84,3.57 \%)$ apparently healthy cats in domiciliary contact with the affected animals (Schubach et al. 2002). Isolation of the fungus from the nails and oral cavities of cats reinforces evidence indicating that transmission can occur through a scratch or bite, whereas isolation from nasal fossae and cutaneous lesions, together with the wealth of yeast-like elements observed in histological sections of skin biopsies (Schubach et al. 2003 b, 2004), demonstrates the possibility of contamination through secretions (Rosser and Dunstan 1998, Kauffman 1999, Schubach et al. 2004). The results of molecular typing of $S$. schenckii isolated from humans and animals support this hypothesis (Reis R, personal communication).

\section{CLINICAL MANIFESTATIONS}

Sporotrichosis has diverse clinical manifestations and investigators disagree regarding the clinical classification of the disease (Lacaz et al. 2002). Below is a schematic presentation of the clinical classi- fication that we consider best from a practical point of view:

$$
\begin{aligned}
& \text { Cutaneous } \\
& \circ \text { Lymphocutaneous } \\
& \circ \text { Fixed } \\
& \circ \text { Disseminated or multiple }
\end{aligned}
$$

Mucosa

- Ocular

- Nasal

- Others

Extracutaneous

- Pulmonary

- Osteoarticular

- Meningeal

- Generalized

Residual (Sequela)
Special Forms

- Spontaneous regression

- Hypersensitivity

(erythema nodosum,

erythema multiforme)

The most frequent clinical form (about 80\%) is the lymphocutaneous form. It starts with a nodular or ulcerated lesion at the site of fungal inoculation and follows a regional lymphatic trajectory characterized by nodular lesions that ulcerate, fistulate and heal, representing true gummae. This clinical description led to naming the disease as 'ascending nodular lymphangitis'. In general, the fixed cutaneous form is characterized by infiltrated nodular, ulcerated or erythematosquamous lesions located on exposed areas where fungal inoculation occurred (Figure 3A). The disseminated cutaneous forms have mainly been observed among immunosuppressed patients, especially HIV-positive individuals (Donabedian et al. 1994, Shaw et al 1989).

Mucosal involvement is not common but may occur, and preferentially affects the ocular mucosa (Figure 4) (Vieira Dias et al. 1997).

Among the extracutaneous forms, osteoarticular and pulmonary involvement are the most com- 


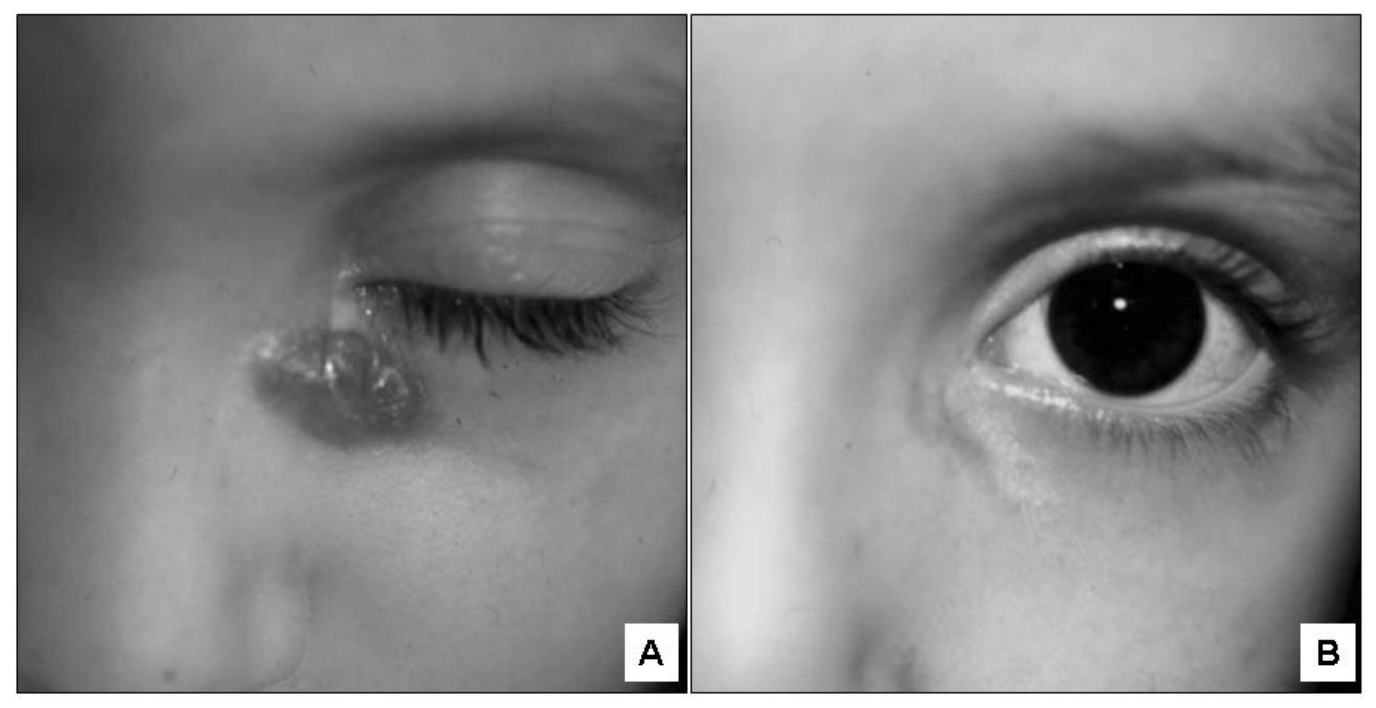

Fig. 3 - Fixed cutaneous form exhibiting a nodular lesion on the face of a child; (A) before treatment and (B) after treatment. The patient was diagnosed by a serological test with the SsCBF antigen.

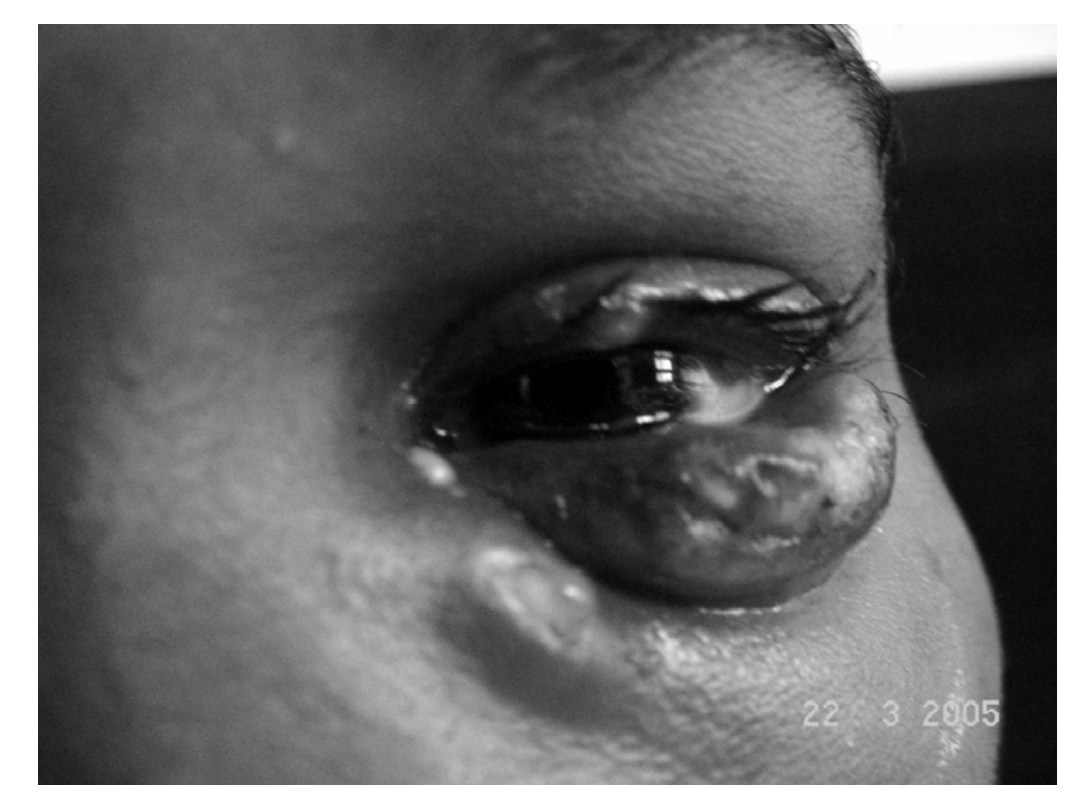

Fig. 4 - Ulcerated granulomatous lesion draining purulent discharge affecting the ocular conjunctiva and surrounding skin in an adolescent girl. 
mon, but there are reports of cases of severe hematogenic dissemination with involvement of multiple organs.

In places with a large number of cases of the disease, reports of spontaneous regression are not rare, nor are the occurrence of hypersensitivity reactions such as erythema nodosum/multiforme (experience of the authors of the present work). Usually, lesions located in the deep dermis or subcutaneous tissue result in skin scars.

\section{REVISION OF THE LITERATURE - CLINICAL SIGNS AND SYMPTOMS OF 178 HUMAN CASES FROM THE EVANDRO CHAGAS RESEARCH INSTITUTE, RIO DE JANEIRO, BETWEEN 1998 AND 2001}

Women patients predominated $(\mathrm{n}=122,68 \%)$ and the age-range was 5 to 89 years old, with a median of 39 years. Among a group of 178 patients, 156 reported domiciliary or professional contact with cats with a suspected or confirmed diagnosis of sporotrichosis, and 97 reported a history of a scratch or bite. The most frequent occupations were domestic activities (30\%) and students (18\%). Five percent of the patients were veterinarians and veterinary assistants. The disease was frequent in women involved in domestic activities and animal care.

Histopathological examination of 73 biopsy fragments revealed a granulomatous infiltrate in 66 $(90.4 \%)$ and the fungus was detected in 21 (28.8\%), corresponding to a high frequency (Barros et al. 2004). The lymphocutaneous form was the most frequent clinical form $(n=95,55.6 \%)$, followed by the fixed cutaneous form $(\mathrm{n}=45,25.3 \%)$ and multiple cutaneous lesions $(n=29,16.3 \%)$ (Barros et al. 2003, 2004). Mucosal involvement was observed in five patients $(2.8 \%)$, affecting the nasal cavity in one and the conjunctiva in four (Schubach et al. 2003a, Barros et al. 2004, Schubach et al. 2005). The lesions varied in morphology including nodules, tubercles, pustules, cysts, gummas, ulcers, ulcerovegetating lesions, verrucous lesions, and plaques accompanied or not by lymphangitis. The predominant sites affected were the upper limbs $(65.2 \%)$, followed by the lower limbs (12.9\%) and the face (6.2\%) (Barros et al. 2004). Arthralgia was a symptom reported by $53(29.8 \%)$ patients and five of them had signs of arthritis (Pereira et al. 2002, Barros et al. 2004). For the first time erythema nodosum (Gutierrez-Galhardo et al. 2002) and erythema multiforme (Gutierrez-Galhardo et al. 2005) were associated with sporotrichosis. These uncommon manifestations might be explained by different mechanisms, such as repeated inoculation during prolonged contact with sick animals, selfinoculation, dissemination of the fungus through the bloodstream, or aspiration of conidia and/or yeasts originating from lesion exudates or from respiratory particles released by sneezing infected cats (Schubach et al. 2002, Barros et al. 2003). Additionally, continuous exposure to large amounts of fungus contaminated materials and subclinical reinfections may result in hypersensitivity (GutierrezGalhardo et al. 2002).

Thirteen $(7.3 \%)$ of the 178 patients showed spontaneous regression of the cutaneous lesions, whereas $165(92.7 \%)$ required specific treatment with itraconazole administered orally at the dose of $100 \mathrm{mg} /$ day for 4 to 36 weeks (median = 12 weeks). Of these 165 patients, $149(90.3 \%)$ were cured and $16(9.7 \%)$ abandoned treatment. Five of the nine diabetic patients required a longer time of treatment (16 to 24 weeks) and the itraconazole dose needed to be increased to $200-400 \mathrm{mg} /$ day in three patients. Four other patients with chronic obstructive pulmonary disease and nine with a history of alcohol abuse responded well to treatment with $100 \mathrm{mg}$ itraconazole/day. All patients were followed up for 6 months to one year after the end of treatment and many of them remained in contact with cats with sporotrichosis. Lesion reactivation was observed in only two patients, who were treated again and cured (Barros et al. 2004).

\section{DIFFERENTIAL DIAGNOSIS}

Due to the diversity of the clinical forms of sporotrichosis, there is also a vast set of differential diagnosis with other pathological conditions. Examples 
include leishmaniasis, nocardiosis, chromomycosis, tuberculosis, rosacea, noninfectious granulomatous diseases, and psoriasis, among others.

\section{S. schenckii ANTIGENS AND LABORATORY DIAGNOSIS}

The role of $S$. schenckii glycopeptide antigens was reported for the first time by González-Ochoa and Figueroa (1947) in precipitation studies and intradermal skin tests using a preparation of antigens isolated from the culture filtrate, called sporotrichin, and antigens isolated from yeast cells. Antigens isolated from both the culture filtrate and the cell wall had been used for intradermal tests in guinea pigs and humans (Nielsen-Jr 1968). Sporotrichin tests, however, have yielded false-positive results in subjects without a history of sporotrichosis (Schneidau et al. 1964). Antigens isolated from the culture filtrate are highly heterogeneous and the positive reactions in intradermal tests and the antigen reactivity in immunodiffusion tests depend on the culture conditions (Takata and Ishizaki 1983).

Intradermal skin tests using sporotrichin as antigen are useful in epidemiological studies and as an auxiliary method in the detection of atypical forms of the disease. As mentioned earlier, however, the intradermal sporotrichin test is not routinely used for the diagnosis of sporotrichosis because it can yield false-positive and false-negative results (Toriello et al. 1991). In 1984, Albornoz et al. proposed the use of immunodiffusion and immunoelectrophoresis tests in the diagnosis of sporotrichosis using a fungal culture filtrate as antigen, in assays employing sera from patients with the disseminated cutaneous form.

The characterization of easily standardized, specific antigens has expanded the possibility of using serological methods as a fast and noninvasive diagnostic tool in systemic mycoses. These methods are mainly used in cases of extracutaneous sporotrichosis or of atypical forms, permitting the selection of an adequate treatment regimen (Scott et al. 1987, Bernardes-Engemann et al. 2005).

Since the cell wall is the surface structure of the fungal cell and therefore mediates the relationship with the host, it represents an important source of antigens. Several studies have been conducted with the objective to isolate and identify antigens on the cell wall of S. schenckii. Epitopes consisting of mono- and dirhamnoside side chains are present in the N-linked chains of the peptidorhamnomannan (Travassos 1989), but cross-react with Streptococcus spp. (Nakamura et al. 1977) and Klebsiella pneumoniae K47 (Ishizaki et al. 1979).

Subsequent studies have demonstrated that some O-glycosidic chains, mainly O-linked tetraand pentasaccharides, carry important antigenic epitopes, $\alpha$-L-Rha $p 1 \rightarrow 2 \alpha$-D-GLcA $p$ and $\alpha$-L-Rha $p$ $1 \rightarrow 4 \alpha$-D-GlcA $p$, which have not been described in other species (Lopes-Alves et al. 1994). Using the reactivity of these O-glycosidic chains against ConA, Lima and Lopes-Bezerra (1997) isolated two subfractions from the peptidorhamnomannan fraction, one of them binding and the other unable to bind to ConA. The ConA-binding fraction, called $S s \mathrm{CBF}$, was specifically recognized by sera from patients with the cutaneous form of sporotrichosis, with the reaction being significantly inhibited by O-linked tetra- and pentasaccharides (Penha and Lopes-Bezerra 2000). This was the first report on a cell wall antigen, purified from $S$. schenckii infective phase, that could potentially be applied in the serodiagnosis of sporotrichosis with good sensitivity. As mentioned, other important carbohydrate epitopes of the yeast phase of $S$. schenckii bearing nonreducing rhamnose end units ( $\operatorname{Rha} p \alpha 1 \rightarrow 3 \operatorname{Man} p$ ) had been described on the cell wall rhamnomannans (reviewed by Travassos 1989). We had shown that this $\mathrm{N}$-linked epitope is also present in the O-linked trisaccharide (Rha $p \alpha 1 \rightarrow 3 \operatorname{Man} p \alpha 1 \rightarrow 2 \operatorname{Man} p$ ) which is expressed in both morphological phases of S. schenckii. This oligosaccharide, however, could only inhibit in $28 \%$ (Table I) the precipitation reaction of the peptidorhamnomannan with a rabbit anti-S. schenckii serum (Lopes-Alves et al. 1994). On the other hand, when the O-linked trisaccharide was assayed together with the O-linked pentasaccharide the inhibition reached $95 \%$ (Table I). Further- 
more, these results were reproduced in inhibition assays with patients " sera demonstrating the presence of $\mathrm{IgG}$ antibodies in human sera against the $\alpha$-LRha $p 1 \rightarrow 4$ [ $\alpha-$ L-Rha $p 1 \rightarrow 2$ ] $\alpha$-D-GlcA $p$ epitope (Penha and Lopes-Bezerra 2000). To our knowledge, the presence of $\alpha$-D-GlcA $p$ units 2,4 disubstituted by rhamnose units has not been described so far in other species.

\section{TABLE I}

\begin{abstract}
Maximum inhibition (\%) of S. schenckii peptidorhamnomannan immunoprecipitation with its derived $O$-linked oligosaccharides (at $1 \mu \mathrm{mol})^{a}$.
\end{abstract}

\begin{tabular}{l|c}
\hline Oligosaccharide & \% inhibition \\
\hline Trisaccharide & 28 \\
\hline Tetrasaccharide & 63 \\
\hline Pentasaccharide & 82 \\
\hline Tri + pentasaccharide & 95 \\
\hline \multicolumn{2}{|c}{${ }^{a}$ Adapted from Lopes-Alves et al. (1994). }
\end{tabular}

Based on these observations, an ELISA test was developed that showed $90 \%$ sensitivity and $86 \%$ overall efficacy when tested against sera obtained from 92 patients with the lymphocutaneous, fixed cutaneous, disseminated cutaneous or multiple and extracutaneous forms of sporotrichosis, in addition to 117 control serum samples obtained from healthy individuals or subjects with other diseases (Bernardes-Engemann et al. 2005). This diagnostic tool seems to be useful not only to promptly diagnose disseminated and atypical forms of this disease but also for those unresolved cases that are negative by the classical mycological test. An example of this condition is the patient shown in Figure 3. The patient was suspected of having fixed cutaneous sporotrichosis but the mycological test gave successive negative results. Several therapeutic regimens were tried without success. After a positive serological result with the SsCBF antigen this patient received the appropriate antifungal therapy which resulted in healing of the lesion (Figure 3B). Recently, we have applied the ELISA test to detect IgG antibodies in other clinical materials such as the synovial fluid and the cerebrospinal fluid (CSF) from two patients with meningeal sporotrichosis and osteoarticular sporotrichosis, respectively. In parallel, we had performed the ELISA test using a mannoprotein fraction (MP) from Saccharomyces cerevisiae as a control. As shown in Figures 5 and 6, we could detect significant levels of anti-SsCBF antibodies in both body fluids. Later on, sporotrichosis was confirmed by the isolation of S. schenckii.

This serological test has also been useful for the therapeutic follow-up of patients (BernardesEngemann et al. 2005).

\section{TREATMENT}

Different drug regimens are used for the treatment of sporotrichosis, including potassium iodide, itraconazole, terbinafine, fluconazole and amphotericin B. The choice is based on the individual's clinical condition, the extent of the cutaneous lesions, assessment of drug interactions and adverse events, and systemic involvement.

Potassium iodide (KI) was the first drug successfully used in the treatment of sporotrichosis. It is formulated as a saturated solution containing approximately $142 \mathrm{~g}$ potassium iodide in $100 \mathrm{~mL}$ water. Treatment is initiated with five drops administered three times a day, and the dose is increased by one drop/dose/day until reaching a total of 4-6 g/day (25-30 drops, three times a day). Indications: localized forms (lymphocutaneous, fixed cutaneous or mucosal forms). Potassium iodide is not recommended during pregnancy (category D). Main adverse events: nausea, metallic taste, hypothyroidism, iododerma, and iodism (Sterling and Heymann 2000, Lesher et al. 1994).

Itraconazole is administered orally at the dose of 100 to $400 \mathrm{mg} /$ day. Indications: the same as described for potassium iodide but the drug is also used for immunosuppressed patients with more extensive clinical forms and systemic involvement. The drug is not indicated during pregnancy 


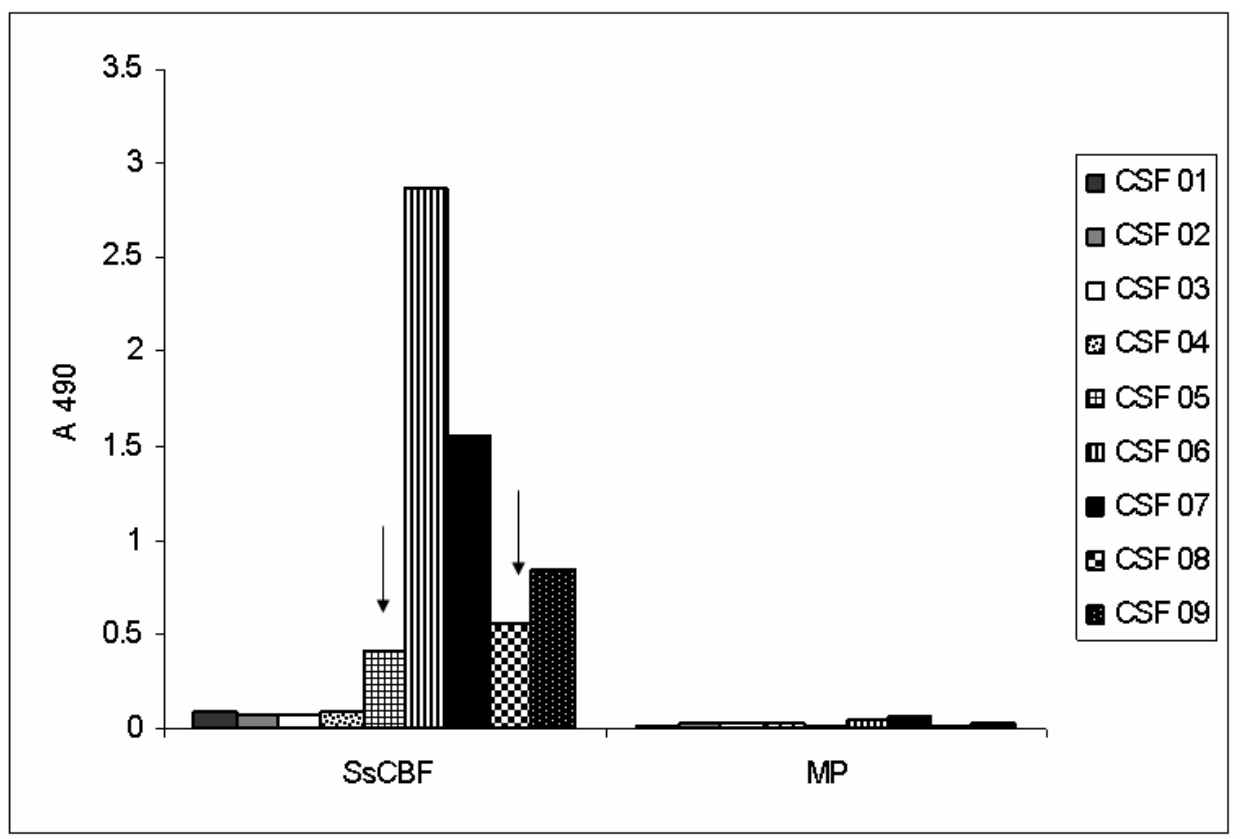

Fig. 5 - Serological follow-up of a patient with meningeal sporotrichosis by the ELISA test with the $\mathrm{SsCBF}$ antigen. Cerebrospinal fluid (CSF) samples were collected in a 18-month period and tested at 1:400 dilution. The presence of cross-reacting IgGs was evaluated with an irrelevant mannoprotein (MP). The black arrows indicate, respectively, a disease recurrence episode and a period of discontinuation of amphotericin B due to its toxic side effects.

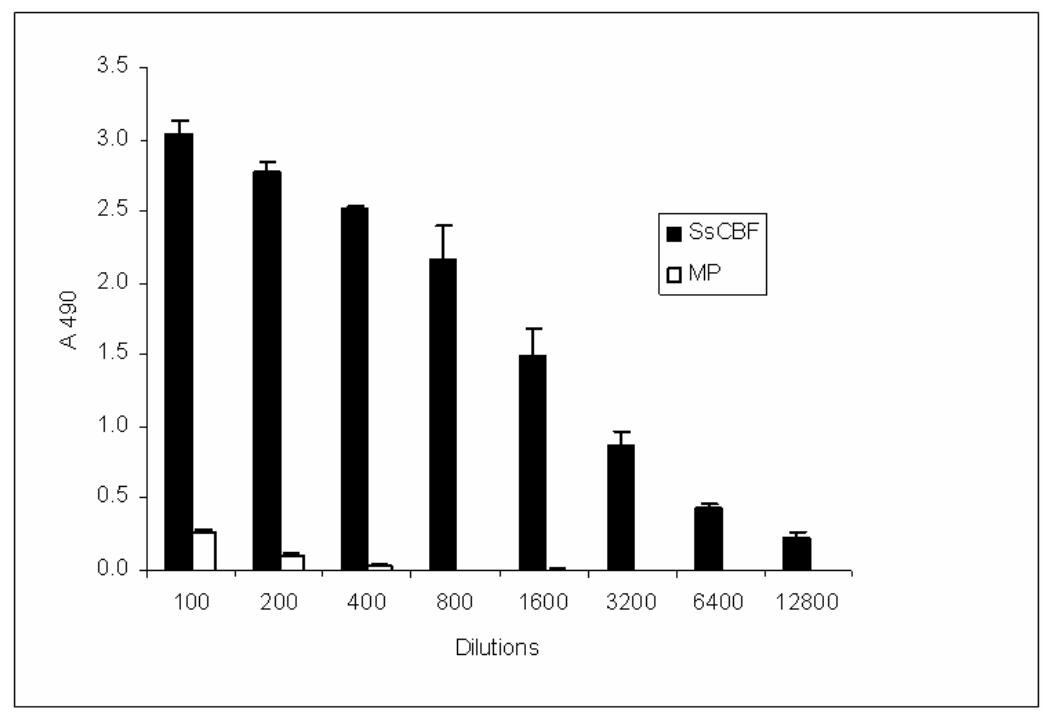

Fig. 6 - Detection of IgG antibodies against the SsCBF antigen in the synovial fluid sample from a patient with osteoarticular sporotrichosis but without exhibiting skin lesions. The synovial fluid was serially diluted (1:2) and assayed either against SsCBF or a mannoprotein from S. cerevisae (MP). 
(category C). Main adverse events: gastrointestinal events such as nausea, vomiting and diarrhea, headache, abdominal pain, hypersensitivity reactions, and liver dysfunction. Drug interactions: interactions with other drugs are numerous, increasing or reducing the action of the antifungal agent or of the concomitantly administered drug, and depend for its activity on enzymes of the cytochrome P-450 system. It is necessary to consult tables and the manufacturer recommendations as well as to evaluate the risks and benefits of drug use (Bolao et al. 1994, Tay et al. 1997).

Terbinafine is not formally indicated for the treatment of sporotrichosis but reports have shown therapeutic success. The present authors have experience with the use of this drug, which has the same indication of itraconazole, is fungicidal, classified as category B for pregnancy. Terbinafine is administered orally at the dose of 250 to $500 \mathrm{mg} /$ day (Hull and Vismer 1992). Main adverse events: gastrointestinal events, headache, taste disturbance, and neutropenia. Drug interactions are also observed but are fewer than those reported for itraconazole.

Reports on the successful treatment with fluconazole are found in the literature, but this is not a first choice drug. Fluconazole is administered orally at 200 to $400 \mathrm{mg} /$ day, but can also be applied intravenously in more severe cases. It also depends on the cytochrome P-450 enzymatic system and is a pregnancy category $\mathrm{C}$ drug.

Amphotericin B is indicated for the treatment of moderate to severe clinical forms in immunosuppressed individuals and those who did not respond to the drugs described above. Amphotericin $\mathrm{B}$ is a pregnancy category $\mathrm{B}$ drug and is nephrotoxic and cardiotoxic. The drug is administered intravenously, with a maximum daily dose of $50 \mathrm{mg}$ and a total cumulative dose of 500 to $1000 \mathrm{mg}$. Depending on the severity of the disease, the patient may later use another drug administered orally (Kauffman 1995).

The duration of treatment until clinical cure is 6 to 8 weeks, on average, in immunocompetent patients.

\section{PROGNOSIS}

The prognosis of sporotrichosis is generally good even in immunosuppressed patients, although its outcome may in a few cases be incapacitating or even fatal.

\section{ACKNOWLEDGMENTS}

L.M.L.B and A.S. are fellowships from the Conselho Nacional de Desenvolvimento Científico e Tecnológico $(\mathrm{CNPq})$. We are grateful to Dr. Luiz R. Travassos for the careful revision and suggestions to improve this manuscript.

\section{RESUMO}

Durante muito tempo a esporotricose foi descrita como uma doença de baixa incidência no Brasil, no entanto, relatos recentes mostram que não só o número de casos descritos vem aumentando como a incidência de formas clínicas mais graves ou atípicas da doença vem ocorrendo com maior frequência. Dados recentes apontam que este grupo clínico já constitui cerca de $10 \%$ dos casos de esporotricose com diagnóstico confirmado. Apresentações clínicas mais raras, principalmente a esporotricose osteoarticular, podem estar associadas tanto a quadros de imunodepressão do paciente quanto à transmissão zoonótica desta doença. O diagnóstico da forma extracutânea ou de formas atípicas é um desafio que tem como ferramenta auxiliar o desenvolvimento recente de um teste sorológico para o diagnóstico das diferentes formas clínicas da esporotricose.

Palavras-chave: esporotricose, diagnóstico, epidemiologia, terapêutica, parede celular, antígenos.

\section{REFERENCES}

Albornoz MP, Villanueva E And Torres ED. 1984. Application of immunoprecipitation techniques to the diagnosis of cutaneous and extracutaneous forms of sporotrichosis. Mycopathologia 85: 177-183.

Alsina A AND RodrigueZ-DEL VAlle N. 1984. Effects of divalent cations and functionally related substances on the yeast to mycelium transition in Sporothrix schenckii. Sabouraudia 22: 1-5. 
BARRos MB ET AL. 2001. Sporotrichosis: an emergent zoonosis in Rio de Janeiro. Mem Inst Oswaldo Cruz 96: 777-779.

Barros Mbl, Schubach aO, Galhardo MC, SCHUBACH TMP, REIS RS, CONCEIÇÃO MJ AND VALLE AC. 2003. Sporotrichosis with widespread cutaneous lesions - a report of 24 cases related to transmission by domestic cats in Rio de Janeiro, Brazil. Int J Dermatol 42: 677-681.

Barros MBL, Schubach A, Francesconi-doVAlle AC, Gutierrez GalHardo MC, CoNCEIÇÃO-SILVA F, SCHUbaCH TMP, REIS RS, MARZOCHI KBF, WANKE B AND CONCEIÇÃO MJ. 2004. Cat-transmitted sporotrichosis epidemic in Rio de Janeiro, Brazil: description of a series of cases. Clin Infect Dis 38: 529-535.

BeEr ZW, HARrington TC, Vismer HF, WingFIELD BD AND Wingfield MJ. 2003. Phylogeny of the Ophiostoma stenoceras-Sporothrix schenckii complex. Mycologia 95: 434-441.

BERNARDES-ENGEMANN AR ET AL. 2005. Improved enzyme-linked immunosorbent assay using the Ss$\mathrm{CBF}$ antigen for the serodiagnosis of several clinical forms of sporotrichosis. Med Mycol 43: 487-493.

Bolao F, Podzamczer D, Ventin M and Gudiol F. 1994. Efficacy of acute phase and maintenance therapy with itraconazole in na AIDS patient with sporotrichosis. Eur J Clin Microbiol Infect Dis 13: 609-611.

Bustamante B and Campos PE. 2001. Endemic sporotrichosis. Curr Opin Infect Dis 14: 145-149.

Campos P, Arenas R and Coronado H. 1994. Epidemic cutaneous sporotrichosis. Int J Dermatol 33: $38-41$.

Castillo MC, Tapia FJ and Arciniegas E. 1990. Ultrastructural localization of specific surface antigens in the dimorphic fungus Sporothrix schenckii. J Med Vet Mycol 28: 91-94.

CDC. 1988. Multistate outbreak of sporotrichosis in seedling handlers. Morb Mortal Wkly Rep 37: 652653.

Chakrabarti A, Roy SK, Dhar S And Kumar B. 1994. Sporotrichosis in north-west India. Indian J Med Res 100: 62-65.

CONTI-DiAZ IA. 1980. Sporotrichosis in Uruguay: Epi- demiologic and clinical aspects. In: (Ed), Pan American Health Organization Scientific Publication, Washington DC: Pan American Health Organization, p. 312-321.

CoOper CR, Dixon DM AND SALKIN IF. 1992. Laboratory-acquired sporotrichosis. J Med Vet Mycol 30: 169-171.

Donabedian H, O’Donnell E, Olszewski C, Macarthur RD ANd Budd N. 1994. Disseminated cutaneous and meningeal sporotrichosis in an AIDS patient. Diagn Microbiol Infect Dis 18: $111-115$.

Dunstan RW, LANGHAM RF, REIMANN KA AND WAKENELL PS. 1986a. Feline sporotrichosis: a report of five cases with transmission to humans. J Am Acad Dermatol 15: 37-45.

Dunstan RW, REIMANN KA AND LANGHAM RF. 1986b. Feline sporotrichosis. J Am Vet Med Assoc 189: 880-883.

EISFELDER M, OKAMOTO S AND TOYAma K. 1993. Experience with 241 sporotrichosis cases in Chiba, Japan. Hautarzt 44: 524-528.

Espinosa-Texis A, Hernandez-Hernandez F, LAVAlle P, BARBA-RUBiO J AND LOPEZ-MARTINEZ R. 2001. Study of 50 patients with sporotrichosis. Clinical and laboratory assessment. Gac Med Mex 137: 111-116.

Figueiredo C, Lima oc, Carvalho L, LopesBEzERRA LM AND Morandi V. 2004. The in vitro interaction of Sporothrix schenckii with human endothelial cells is modulated by cytokines and involves endothelial surface molecules. Microb Pathog 36: $177-188$.

Fischman O, Alchorne MM And Portugal MA. 1973. Human sporotrichosis following rat bite. Rev Inst Med Trop São Paulo 15: 99-102.

FUKUSHIRO R. 1984. Epidemiology and ecology of sporotrichosis in Japan. Zentralbl Bakteriol Mikrobiol Hyg [A] 257: 228-233.

GARRISON RG AND MIRIKITANI FK. 1983. Electron cytochemical demonstration of the capsule of yeastlike Sporothrix schenckii. Sabouraudia 21: 167-170.

GonZÁLEZ-OCHOA A. 1965. Contribuciones recientes al conociemiento de la esporotrichosis. Gac Med Mex 95: 463-474. 
GonZÁlez-OchoA A And Figueroa ES. 1947. Polisacaridos del Sporotrichum schenckii. Dados eptidegicos. Intradermo-reacción en el diagnóstico de la esporotricose. Rev Inst Salubr Enferm Trop Mexico City 8: 143-153.

Gorin PAJ, Haskins RH, TRAVASSOS LR AND MendonçA-Previato L. 1977. Further studies on the rhamnomannans and acidic rhamnomannans of Sporothrix schenckii and Ceratocystis stenoceras. Carbohydr Res 55: 21-33.

Gutierrez-Galmardo MC, Schubach AO, BarROS MBL, BLANCO TCM, CUZZI-MAYA T, SCHUBACH TMP, LAZÉRA MS AND FRANCESCONI-DO-VALLE AC. 2002. Erythema nodosum associated with sporotrichosis. Int J Dermatol 41: 114-116.

Gutierrez-Galhardo MC, Barros MBL, SchuBACH A, CUZZI T, SCHUBACH TMP, LAZÉRA MS AND FRANCESCONI-DO-VALLE ACF. 2005. Erythema multiforme associated with sporotrichosis. J Eur Acad Dermatol Venereolol 19: 507-509.

Hektoen L And Perkins CF. 1900. Refractory subcutaneous caused by Sporothrix schenckii. A new pathogenic fungus. J Exp Med 5: 77-89.

HOWARD DH. 1961. Dimorphism of Sporotrichum schenckii. J Bacteriol 81: 464-469.

HULl PR AND VISMER HF. 1992. Treatment of cutaneous sporotrichosis with terbinafine. British J Dermatol 126 (Suppl.) 39: 51-52.

ISHIZAKI H. 1970. Some antigenic substances from culture filtrate of Sporothrix schenckii. Japan J Dermatol 80, Ser. B: 16-23.

ISHIZAKI H, NAKAMURA Y AND WHEAT RW. 1979. Comparative immunochemical studies on Sporothrix species. J Dermatol 6: 317-320.

ITOH M, OKAмото S AND KARIYA H. 1986. Survey of 200 cases of sporotrichosis. Dermatologica 172: 209-213.

KAUFFMAN CA. 1995. Old and new therapies for sporotrichosis. Clin Infect Dis 21: 981-985.

Kauffman CA. 1999. Sporotrichosis. Clin Infect Dis 29: 231-236; quiz 237.

Kusuhara M, Hachisuka H AND SASAi Y. 1988. Statistical survey of 150 cases with sporotrichosis. Mycopathologia 102: 129-133.
Kwon-Chung K and Bennett J. 1992. Sporotrichosis. In: KwON-CHUNG K ET AL. (Eds), Medical Mycology, Philadelphia: Lea \& Febiger, p. 707-729.

LACAZ CS. 1998. Sporothrix schenckii. In: LACAZ CS ET AL. (Eds), Guia para identificação: fungos, actinomicetos e algas de interesse médico. São Paulo: Sarvier, p. 326-331.

Lacaz CS, Porto E, Martins JeC, Heins-VaCCARI EM AND MElo NT. 2002. Tratado de Micologia Médica, Savier (Ed), São Paulo, 9a ed., p. 479-497.

Larsson CE, Goncalves MA, Araujo VC, Dagli ML, Correa B and Fava Neto C. 1989. Feline sporotrichosis: clinical and zoonotic aspects. Rev Inst Med Trop São Paulo 31: 351-358.

Lesher JL, Fitch MH AND DUNLAP DB. 1994. Subclinical hypothyroidism during potassium iodide therapy for lymphocutaneous sporotrichosis. Cutis 53: $128-130$.

LimA OC AND LOPES-BEZERRA LM. 1997. Identification of a concanavalin A-binding antigen of the cell surface of Sporothrix schenckii. J Med Vet Mycol 35: 167-172.

Lima oc, Figueiredo C, Previato Jo, MenDonÇa-Previato L, Morandi V AND LopesBEZERRA LM. 2001. Involvement of fungal cell wall components in adhesion of Sporothrix schenckii to human fibronectin. Infect Immun 69: 6874-6880.

Lima OC, Bouchara JP, Renier G, Marot-LeBlond A, Chabasse D AND Lopes-Bezerra LM. 2004. Immunofluorescence and flow cytometry analysis of fibronectin and laminin binding to Sporothrix schenckii yeast cells and conidia. Microb Pathog 37: 131-140.

LLOYD KO AND BITOON MA. 1971. Isolation and purification of a peptido-rhamnomannan from the yeast form of Sporothrix schenckii. Structural and immunochemical studies. J Immunol 107: 663-671.

LLOYD KO AND TRAVASSOS LR. 1975. Immunochemical studies on L-rhamno-D-mannans of Sporothrix schenckii and related fungi by using rabbit and human antisera. Carbohydr Res 40: 89-97.

Lloyd KO, MENDONÇA-PREviato L And TravasSOS LR. 1978. Distribution of antigenic polysaccharides in differente cell types of Sporothrix schenckii 
as studied by immunofluorescence staining with rabbit antisera. Exp Mycol 2: 130-137.

Lopes Jo, Alves SH, Mari CR, Brum LM, Westphalen JB, Altermann MJ and Prates FB. 1999. Epidemiology of sporotrichosis in the central region of Rio Grande do Sul. Rev Soc Bras Med Trop 32: 541-545.

Lopes-Alves LM, Mendonça-Previato L, FourNet D, Degant P and Previato JO. 1992. Oglycosidically linked oligosaccharides from peptidorhamnomannans of Sporothrix schenckii. Glycoconj J 9: 75-81.

Lopes-Alves LM, Travassos LR, Previato JO And MendonçA-Previato L. 1994. Novel antigenic determinants from peptidorhamnomannans of Sporothrix schenckii. Glycobiology 4: 281-288.

LUTZ A AND SPLENDORE A. 1907. Sobre uma mycose observada em homens e ratos. Rev Med São Paulo 21: 433-450.

Lyon GM, Zurita S, Casquero J, Holgado W, Guevara J, Brandt ME, Douglas S, Shutt K, WARNOCK DW AND HAJJEH RA. 2003. Population-based surveillance and a case-control study of risk factors for endemic lymphocutaneous sporotrichosis in Peru. Clin Infect Dis 36: 34-39.

Mackinnon J, Conti Diaz I, Gezuele E, Civila E AND DA LUZ S. 1969. Isolation of Sporothrix schenckii from nature and considerations on its pathogenicity and ecology. Sabouraudia 7: 38-45.

MARIAT F. 1968. The epidemiology of sporotrichosis. In: Wolstenholme GEW (Ed), Systemic Mycoses. London, A Churchill, p. 144-159.

MARIAT F. 1971. Adaptation de Ceratocystis à la vie parasitaire chez l'animal. Étude de l'aquisition d'un pouvoir pathogène comparable à celui de Sporothrix schenckii. Sabouraudia 9: 191-205.

Mayorga R, Caceres A, Toriello C, Gutierrez G, Alvarez O, Ramirez ME and Mariat F. 1978. An endemic area of sporotrichosis in Guatemala. Sabouraudia 16: 185-198.

Mayorga R, Caceres A, Toriello C, Gutierrez G, Alvarez O, Ramirez ME and Mariat F. 1979. Study of an endemic sporotrichosis zone in the Ayarza lake region of Guatemala. Bol Oficina Sanit Panam 87: 20-34.
Mendonça L, Gorin PAJ, Lloyd KO And TraVASsOS LR. 1976. Polymorphism of Sporothrix schenckii surface polysaccharides as a function of morphological differentiation. Biochemistry 15: 2423-2431.

Mendonça-Previato L, Gorin PAJ And TravasSOS LR. 1980. Galactose-containing polysaccharides from the human pathogen Sporothrix schenckii. Infect Immun 29: 934-939.

MoORE J AND DAVIS D. 1918. Sporotrichosis following mouse bite with certain immunologic data. J Infect Dis 23: 252-265.

Morris-Jones R, YoungChim S, Gomez BL, Aisen P, Ray RJ, Nosanchuk JD, CASAdeVALl A AND HAmilton AJ. 2003. Synthesis of melanin-like pigments by Sporothrix schenckii in vitro and during mammalian infection. Infect Immun 71: 4026-4033.

MUIR DB AND PRITCHARD RC. 1984. Sporothrix schenckii - incidence in the Sydney region. Australas J Dermatol 25: 27-28.

NAKAMURA Y. 1976. Purification and isolation of a biologically active peptido-rhamnogalactan from to Sporothrix schenckii. J Dermatol 3: 25-29.

NAKAMURA Y, IShIZAKI H AND WheAT RW. 1977. Serological cross-reactivity between group B Streptococcus and Sporothrix schenckii, Ceratocystis species, and Graphium species. Infect Immun 16: 547-549.

NiELSEN-JR HS. 1968. Biological properties of skin test antigens of yeast form Sporotrichum schenckii. J Infect Dis 118: 173-180.

Pappas PG, Tellez I, Deep AE, Nolasco D, HolGado W And Bustamante B. 2000. Sporotrichosis in Peru: Description of an area of hyperendemicity. Clin Infect Dis 30: 65-70.

Penha CVL And Lopes-Bezerra LM. 2000. Concanavalin A-binding cell wall antigens of Sporothrix schenckii: a serological study. Med Mycol 38: 1-7.

Pereira AC, LeVy RA, BARros MBL, Schubach TMP, SCHUBACH AO, FranCESCONI-DO-VALlE AC, Conceição-Silva F, DE-LuCA PM AND Gutierrez-GalHardo MC. 2002. Manifestações articulares da esporotricose no Rio de Janeiro. Rev Bras Reumatol 42: S4. 
Previato Jo, Gorin PAJ, Haskins RH and TraVASSOS LR. 1979. Soluble and insoluble glucans from different cell types of Sporothrix schenckii. Exp Mycol 3: 92-105.

QuinTAL D. 2000. Sporotrichosis infection on mines of the Witwatersrand. J Cutan Med Surg 4: 51-54.

READ SI AND SPERLING LC. 1982. Feline sporotrichosis. Transmission to man. Arch Dermatol 118: 429-431.

ReEd KD, Moore FM, Geiger GE And Stemper ME. 1993. Zoonotic transmission of sporotrichosis: case report and review. Clin Infect Dis 16: 384-387.

RIPPON JW. 1988. Medical Mycology. The Pathogenic Fungi and Pathogenic Actinomycetes, $3^{\text {rd }}$ ed., Philadelphia: WB Saunders Company, p. 325-352.

Rodriguez-del Valle N, Rosario M and TorRES BLASINI G. 1983. Effects of $\mathrm{pH}$, temperature, aeration and carbon source on the development of the mycelial or yeast forms of Sporothrix schenckii from conidia. Mycopathologia 82: 83-88.

Romero-Martinez R, WheEler M, GuerreroPlata A, Rico G and Torres-Guerrero $\mathrm{H}$. 2000. Biosynthesis and function of melanin in Sporothrix schenckii. Infect Immun 68: 3696-3703.

Rosser E AND DUnSTAN R. 1998. Sporotrichosis. In: GREENE C (Ed), Infectious Diseases of the Dog and Cat, Philadelphia WB Saunders Company, p. 399-402.

SCHENK B. 1898. On refractory subcutaneous abscesses caused by a fungus possibly related to sporotrichia. John Hopkins Hosp 9: 286-290.

SCHNEIDAU JD, LAMAR LM AND HAIRSTON MA. 1964. Cutaneous hypersensitivity to sporotrichin in Louisiana. JAMA 188: 371-373.

SCHUBACH A ET AL. 2005. Primary conjunctival sporotrichosis: two cases from a zoonotic epidemic in Rio de Janeiro, Brazil. Cornea 24: 491-493.

Schubach AO. 2003a. Esporotricose primária da mucosa nasal. Rev Soc Bras Med Trop 36: 222.

SCHUBACH TM ET AL. 2002. Sporothrix schenckii isolated from domestic cats with and without sporotrichosis in Rio de Janeiro, Brazil. Mycopathologia 153: 83-86.

SCHUBACH TM, SchubaCH AO, CUZZI-MAYA T, OKAmoto T, ReIS RS, Monteiro PC, GU-
TIERREZ-GALHARDO MC AND WANKE B. 2003b. Pathology of sporotrichosis in 10 cats in Rio de Janeiro. Vet Rec 152: 172-175.

Schubach TMP AND Schubach A. 2000. Sporotrichosis of cat and dog - review. Clin Vet 29: 21-24.

SCHUBACH TMP, SCHUBACH A, OKAMOTO T, BARRos MBL, Figueiredo FB, Cuzzi T, FialhoMonteiro PC, Reis RS, Perez MA ANd WANKE B. 2004. Evaluation of an epidemic of sporotrichosis in cats: 347 cases (1998-2001). J Am Vet Med Assoc 224: 1623-1629.

SCHUBACH TMP ET AL. 2006. Canine sporotrichosis in Rio de Janeiro, Brazil: clinical presentation, laboratory diagnosis and therapeutic response in 44 cases (1998-2003). Med Mycol 44: 87-92.

ScotT EN, Kaufman L, Brown AC AND MuchMORE HG. 1987. Serologic studies in the diagnosis and management of meningitis due to Sporothrix schenckii. N Engl J Med 317: 935-940.

ShaW JC, Levinson W and Montanaro A. 1989. Sporotrichosis in the acquired immunodeficiency syndrome. J Acad Am Dermatol 21: 1145-1147.

Sterling JB and Heymann WR. 2000. Potassium iodide in dermatology: A $19^{\text {th }}$ century drug for the $21^{\text {st }}$ century - uses, pharmacology, adverse effects, and contraindications. J Am Acad Dermatol 43: 691-697.

TAKATA M AND ISHIZAKI H. 1983. Correlations among culture times, sugar composition and biological activities of Sporothrix schenckii antigens. Mycopathologia 84: 31-39.

TAY YK, GOH CL AND ONG BH. 1997. Sporotrichosis: A case report and successful treatment with itraconazole. Cutis 60: 87-90.

TAYLOR JJ. 1970. A comparison of some Ceratocystis species with Sporothrix schenckii. Mycopath Mycol Appl 42: 233-240.

THOMPSON DW AND KAPLAN W. 1977. Laboratoryacquired sporotrichosis. Sabouraudia 15: 167-170.

Toriello C, ArJona-Rosado LC, Diaz-Gomez ML AND TAYLOR ML. 1991. Efficiency of crude and purified fungal antigens in serodiagnosis to discriminate mycotic from other respiratory diseases. Mycoses 34: 133-140.

TraVASSOS LR. 1985. Sporothrix schenckii. In: SZANISZLO PJ (Ed), Dimorphism, with emphasis on 
fungi pathogenic for humans, New York: Plenum Press, p. 121-163.

TraVASSOS LR. 1989. Antigenic structures of Sporothrix schenckii. In: Immunology of fungal diseases. Kurstak E (Ed), Marcel Dekker, New York; p. 193-221.

Travassos LR AND LlOYd KO. 1980. Sporothrix schenckii and related species of Ceratocystis. Microbiol Rev 44: 683-721.

Travassos LR, Gorin PAJ AND Lloyd KO. 1973. Comparison of the rhamnomannans from the human pathogen Sporothrix schenckii with those from the Ceratocystis species. Infect Immun 8: 685-693.

Travassos LR, Gorin PAJ AND LlOYd KO. 1974. Discrimination between Sporothrix schenckii and Ceratocystis stenoceras rhamnomannans by proton and carbon-13 magnetic resonance spectroscopy. Infect Immun 9: 674-680.
Travassos LR, Souza W, Mendonça-Previato L AND LLOYD KO. 1977. Location and biochemical nature pf surface components reacting with concanavalin A in different cell tyoes of Sporothrix schenckii. Exp Mycol 1: 293-305.

Vieira-Dias D, Sena CM, Oréfice F, Tanure MAG AND HAMDAN JS. 1997. Ocular and concomitant cutaneous sporotrichosis. Mycoses 40: 197-201.

VISMER HF AND Hull PR. 1997. Prevalence, epidemiology and geographical distribution of Sporothrix schenckii infections in Gauteng, South Africa. Mycopathologia 137: 137-143.

Werner AH AND Werner BE. 1994. Sporotrichosis in man and animal. Int J Dermatol 33: 692-700. 